\title{
MIMNERMUS' IMAGES OF YOUTH AND AGE*
}

\section{W.J. Henderson, Rand Afrikaans University}

The poet who created the most important ancient Greek elegiac poetry on the transience of youth and love, and on the consequent necessity to enjoy youth and love while one could, is Mimnermus of Colophon (end 7th century B.C.). Wolfgang Schadewaldt formulated his contribution as follows: "Aber sein Aufruf zum Genuß der Jugend und ihrer naturgemäßen Gabe, der Liebe, ist die entschiedenste und in aller Zeitmüdigkeit auch kräftigste Folgerung jenes Grauens vor dem Nahen des Alters" (1933:295).1 In five fragments Mimnermus deals with the beauty and joy of youth as opposed to the physical degeneration and suffering of age in terms which portray existence after the passing of youth very negatively, and which have brought on him the criticism of pessimism.2 Equally important is his use of images to embody these themes. Bowra speaks of "his brilliant sustained images" (1970:688) and several critics have written on this aspect of Mimnermus' poetry. This article explores more closely the nature of Mimnermus' use of images in connection with his treatment of youth and age, in order to highlight a previously unnoticed tendency in the relationship between imagery and description.

Mimnermus' position is clearly expressed in fragment 1 West 1972, Edmonds 1968 (Text 1). The gifts and influence of Aphrodite are used as the measure for the meaning of life: without them life is not worthwhile $(1-5,8)$. Age brings pain (5b), loss of physical attractiveness, intellectual and spiritual power $(6,9)$, and loss of pleasure (8); and anxiety appears (7). Such a criterium for personal happiness is something significant in the

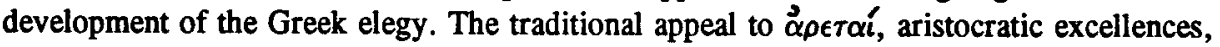
such as one finds in Tyrtaeus, for the benefit of the group, are set aside in favour of an erotic ideal to achieve individual happiness. The paraenesis is now carpe diem: enjoy life

- This paper was prepared during sabbatical leave at the Seminar für kdassische Philologie, University of Basel, in 1993. I wish to thank Professor Joachim Latacz and Mr René Nünlist for their kindness and assistance. Financial support by the Centre for Science Development is hereby acknowledged. Opinions expressed in this paper are those of the author, and should therefore not be ascribed to the CSD.

1 Gentili 1965:379-380 evalutes Mimnermus as follows: "È una voce nuova nella cultura arcaica, cresciuta nell'ambiente del comos e dell'aulodia ..., disancorata dalla ufficialità della tradizione rapsodica, di dimensione ambientale diversa da quella ottimistica di Solone ... e totalmente pessimistica di Semonide d'Amorgo ..., nuova per l'originalità del tema, della scrittura, delle dolci cadenze ritmiche ..., e delle rime auditive e visive ..., e forse anche per una estrosa inventività musicale ..." . He further identifies the antithesis between youth and age as the "sigillo personale" of Mimnermus (380). Cf. also Lesky 1966:120-121. Ancient judgements of Mimnermus' poetry focus on his "sweetness" (melodious diction), polished versification (Callim. Aitia Ox. Pap. 2079.11-12; Hermesianax ap. Athen. 13.597f), and treatment of the love-theme (Propertius regarded him as superior to Homer in this respect: "plus in amore valet Mimnermi versus Homero", 1.9.11). Horace (Epi. 1.6.65-66) recognised the carpe diem motif.

2 Babut (1971:31-35) finds Mimnermus even more pessimistic than Semonides, because the former's expression is so deeply personal. However, he argues that Mimnermus does not lapse into total pessimism, since he at least allows genuine pleasure and happiness for youth. 
(and the gifts of Aphrodite in particular) while you are young. 3 There is a positive message at the centre of the pessimistic mood.4

Two sets of images embody the antithesis between youth and age. On the one side, that of youth and love, there are the "gold" of Aphrodite and the "flowers" of youth - both with strong positive associations. On the other side, that of age, there is only one rather weak image, with negative associations: cares that "oppress" or "wear out" ( $\tau \epsilon i$ povol) the human heart, a usage found often in Homer. "Golden Aphrodite" is itself a conventional expression in Homer (cf. Campbell 1982:224; Barkhuizen, Henderson \& Van Rooy 1986:93). The "flower of youth" also appears in Homer, where it is applied to Aeneas (Il. 13.484).5 Gentili (1965:384) has, however, acutely indicated that there are important differences in Mimnermus' use of the flower-image: superficial differences such as a new rhythm in the elegiac couplet, patterns of assonance, and enjambement between pentameter and hexameter, but also conceptual differences: in Homer the "flower" of Aeneas' youth typifies only his physical attractiveness and strength, while in Mimnermus it represents the desirable phase of life, the onset of love for men and women. What is also noticeable is that positive and attractive imagery is applied to youth, while only very weak imagery is used of age. For the latter, realistic description is preferred (5-10). The difference in the type of imagery is to be expected, as the images are generated by the theme and thought. What seems significant, however, is the structural function of imagery (used of youth) versus description (used of old-age).

When the flower-image appears again (fragment 2 West, Edmonds), there is a negative aspect: the brevity of the flowers and of youth (Text 2). Käthe Dietel (1939:13-14) has already shown that the "Ansatzpunkt" with the flowers was not only the brevity of their existence, but that positive associations were being activated: the total blossoming and sprouting of spring announced by the flowers; the joy and pleasure of nature in the spring, which then becomes the image of the spring of life; a "heller Glanz" that hangs over all. Against this, the transience itself is highlighted "als bei Mimnermos das Alter gar keine Schönheit, gar kein Gut hat; alles Licht liegt allein bei der $\stackrel{\| \prime}{\eta} \beta \eta$. Desto schmerzlicher ist ihre kurze Dauer" (14). 6

She also draws a comparison between Homer's and Mimnermus' use of the leaf-simile with which the fragment opens. The tertium comparationis in the Homer-simile (Il. 2.467-468,

3 Semonides also treats the theme of the futility of human hopes, but the carpe diem motif in Mimnermus is distinctive; cf. Schadewaldt (1933:294-295) and Babut (1971:18-29, 39-40). Latacz (1991:176-179) compares Mimnermus with his older contemporaries, Callinus and Tyrtaeus, and points out that Mimnermus does not use his verse as an instrument to "heal" his community, but concentrates instead on "Wirklichkeitsveränderung" and "Klangschōnheit".

4 Gentili 1965:383 accurately and finely formulates the relation between pessimism and the positive element: "All'ideale eroico dell'epica è opposto un ideale piu umano, ... il piacere dell'amore: una concezione non proprio edonistica ..., ma pessimistica, non piu aristocratica ma borghese, espressione di quella incipiente crisi dei valori erotici che coincise nella seconda metà del VII secolo ... I valori di richezza, forza, prestanza, successo, gradualmente declinano per lasciare posto ad un'idea della vita piú coerente con la caduca natura dell'uomo. Il piacere dell'amore, sebbene evanescente ed effimero, tuttavia pur sempre piacere, quindi un valore, anche se di breve durata, il sommo valore nell'età piú felice della vita, la giovinezza."

5 Latacz (1991:185 n.7) cites Hom. Il. 6.146ff. and Semonides fragment 29 Diehl for the "wohl uraltes Gleichnis".

6 Few scholars refer to this still useful study, supervised by Rudolph Pfeiffer until his flight to England from Nazi Germany. Nothing seems to be known of dr. Dietel after the war. 
800; cf. also 6.146; Od. 96.105-106) is the great number of the generations of mortals, which does not have much significance in Mimnermus. The comparison at $O d .9 .51$ is closer, because flowers and spring are also involved (cf. also $l l$. 21.464), and Homer visualises the arrival of new leaves (generations), and therefore implies the theme of transience (cf. Griffith 1976:75-77; Goldhill 1991:77-78). The difference is, however, that Homer embraces the whole human life-cycle, while Mimnermus concentrates only on the brevity of youth. "Damit hat er dem Bild aus dem Epos seine ganz besondere Note gegeben" (Dietel 1939:15), in order to fit it into his own view of life.7 "Sie (the comparisons) sind aber nicht nur Schmuck, sondern stehen in inniger Verbindung mit seiner Lebensauffassung, die auch in der besonderen Wahl der Bilder zum Ausdruck kommt" (Dietel 1939:17).

There is, however, more to be said about the nature of the imagery. The flowers are now a part of a larger image: the plant-life in the seasons. As such they are subject to the natural laws that govern the seasons. Further images enforce the idea of the brevity of youth: spring-leaves and flowers that appear suddenly and then wither (1-4), the duration of daylight (7-8), a harvest that ripens (7-8). The latter image belongs to autumn, but Mimnermus visualises no summer or autumn or winter of life - only spring enjoys his attention. He telescopes the passage of the seasons, and this achieves the effect of a swiftly vanishing period of bloom (= youth); other phases of life are ignored in the imagery. There is only a reference to the spirits of death, the $x \hat{\eta} \rho \epsilon \varsigma$ (5), which, in contrast to the brief but colourful flowers, are described as "black" ( $\mu$ é $\lambda \alpha \iota \nu \alpha \iota)$. Youth is evoked in a complex nexus of imagery, loaded with positive associations. Age and its concommitant ills are, as in fragment 1 , formulated with a minimum of imagery.

In the antithesis between youth and age the description of old-age dominates the fragment. This was noticed by Schadewaldt: "Die Jugend ganz im Ergötzen gesehen, das Alter, hier wie in anderen Gedichten (Fr. 3.4.5), viel reicher beschrieben als die Jugend - eben weil Altersfurcht und nicht Genußfreude die Grundstimmung ist, aus der Mimnermos schafft und lehrt" (1933:296).8 Again, as in fragment 1, imagery and description have a structural role. The long descriptions of the ills and pains of old-age that are set against the brief but "active" and vital images of youth actually embody in the structure of the poem the reality of human life as Mimnermus saw it. Youth is conjured up in rich images, age described in abhorrent realistic details. The former is poetic and suggestive, the latter narrative and explicit.

The next idea in the fragment is complex, and has elicited a great deal of discussion: the gods give young people no foreknowledge of good and evil. Their consequent innocence and ignorance contribute to their happiness (4-5) (cf. Gerber 1975:263-268; 1976:77-78; Barkhuizen, Henderson \& Van Rooy 1986:98-99, 101-102). It is therefore implied that precisely such knowledge of good and evil mars the happiness of the aged.

Then Mimnermus refers to two fates that confront mortals: either a long and painful oldage, or death (5-7). This is a surprising variation (what is, after all, the choice?) of the revelation that Thetis gives her son Achilles in Homer (II.9.410-416), namely Achilles' choice between a glorious but short life with $\kappa \lambda \hat{\epsilon} \sigma \varsigma$, or a long life spent in peaceful

7 Griffith (1976:77) also points out the "more personal note" and makes a similar comparison between the views of Homer and Mimnermus (81-82).

8 Schmiel (1974:283-289) may be right in thinking that in poem 1 Mimnermus seems to be writing from the view-point of youth, with the ills of old-age still in the unseen future; and in poem 2 looks back, as an old man, with the cares and pains of old-age upon him, on his past, fleeting youth. 
obscurity (cf. Dawson 1966:44-47; Griffith 1976:78-79; Goldhill 1991:69-108). For Mimnermus an early death is the best alternative after brief youth (7-10). Elsewhere Mimnermus refers to a mythological exemplum of the first type of fate: that of Tithonus who grew ever older until he turned into a locust (fragment 4 West) - again a quite negative image.

The pessimism lies for us in Mimnermus' totally negative view of old-age: for him there are no advantages at all in the later phases of human life. 9 Here we must, however, remind ourselves of the contemporary situation. In ancient Greece the lot of the aged was indeed desperate: no old-age homes or hospitals, no medical and social services and assistance, no pension funds, no media for information or entertainment, no aids for failing hearing, eyesight and mobility, no more useful role in society. The elderly were entirely dependent on their children, and a childless old-age was nothing less than a disaster, especially for care and eventual burial (cf. Eur. Alc. 654-672; Med. 1032-1037).10 Mimnermus' view of old-age is in fact very realistic (cf. also Barkhuizen, Henderson \& Van Rooy 1986:92-96).

Other disadvantages of old-age are spelt out and imagery employed in one other fragment (5 West, Edmonds) (Text 3). Again the flower-image appears for beautiful youth (2-3), but

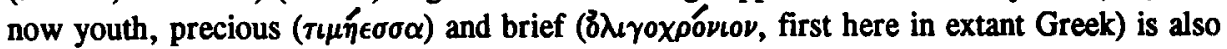

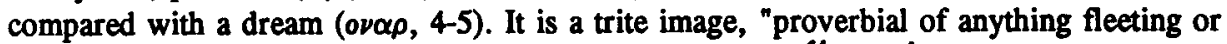

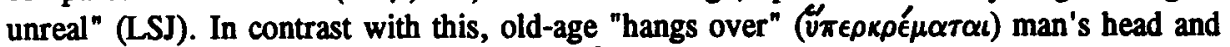
"is poured on" or "shed around" ( $\alpha \mu \varphi\left(\chi \cup \in \epsilon^{\prime} \nu\right)$ his eyes and thought. These are not trite or weak images. The two verbs appear in a figurative sense only in poets after Mimnermus, the first only in Theognis (1022, which is a direct quote of this fragment), the latter in Homer (Il. 2.41, of a voice in a dream; and Od. 4.716, of pain) and Euripides (Supp. 826, of ashes). The tendency noticed so far has therefore been reversed: the weak imagery is used of youth, the strong and suggestive imagery applied to old-age. The connotations in the latter are, however, still negative, the idea of heaviness and oppression dominating (as in fragment 1). Also, realistic description still takes up much of lines 5-8: the elderly person is unloved, unhonoured, forgotten.

The difference in the way the imagery is applied could be explained by challenging Mimnermus' authorship. This fragment appears, with only slight differences in the last two lines, in Theognis 1017-1022. However, the editors agree that, though the first three lines may be Theognis', lines 4-8 (which contain our images) are Mimnermus'.11 One may also suggest that this fragment comes from another collection, the Nanno, and therefore shows a different attitude and expression, but lack of context and sufficient text obviate any judgement along that route.

There is a further twist to this theme. With such a dismal prospect of old-age, Mimnermus actually expresses the wish to die at the age of sixty, before disease and the other ailments

9 Cf. Schadewaldt: "Also nur die Jugend ist Leben, Alter ist schlimmer als Tod" (1933:296).

10 Babut 1971:36-37 brings the totally negative view of old-age (loss of wealth and health, after all, does not only affect the elderly) into connection with the ancient mentality of visualising everything "au principe de polarite." Griffith 1976:80 also recognises the "practical realities" of a childless old-age, but ties it especially to children as a remedy against "obscurity and neglect from posterity." Mimnermus states, too, that even the attitude of the old man's children changes towards him (fragment 3 West).

11 Edmonds (1968:92, 93 n.1) regards the ascription of lines 1-3 to Mimnermus as doubtful; West (1972:84) prints the text as a whole, and repeats it at Theognis 1017-1022; and Gentili-Prato (1979) omits lines 1-3 as Theognidean. 
of the elderly harass him (fragment 6 West, 11 Edmonds) (Text 4). The thought, in view of all that has been said, seems strange. It negates the pessimistic view encountered in other fragments. Sixty is, after all, no-longer life's spring-time. In fact, given the low life expectancy of ancient populations (one was already old at 45), sixty is quite old. The only way out of the contradiction is to suggest that it is not so much old-age itself that Mimnermus would shun, but the physical and spiritual suffering that accompanies it. Fragment 6 states as much, but it is also brought out by the tendency to portray youth in brief, attractive images, and old-age in lengthy realistic description. Image and description both add their particular contribution to the text: not only thoughts and associations, but also the structural fabric of the poem. Whether this was typical of Mimnermus' use of imagery is impossible to tell from the surviving fragments. It is equally possible that the variation in fragment 5 suggests that this particular relation of image to description may have been limited to fragments 1 and 2 .

\section{BIBLIOGRAPHY}

Babut, D. 1971. "Sémonide et Mimnerme." REG 84:17-43.

Barkhuizen, J.H., Henderson, W.J. \& Van Rooy, C.A. 1986. Kalliope, Band I: Griekse jambiese en elegiese poessie van Archilochos tot Theognis. Pretoria: Unisa.

Bowra, C.M. 1970. "Mimnermus" in: Hammond, N.G.L. \& Scullard, H.H. (eds), The Oxford Classical Dictionary (2nd edition). Oxford: Clarendon Press, 688.

Campbell, D.A. 1982. Greek Lyric Poetry. A Selection of Early Greek Lyric, Elegiac \& Iambic Poetry. Bristol: Classical Press.

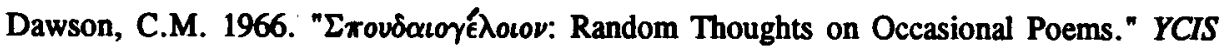
19:39-47.

Dietel, Kăthe. 1939. Das Gleichnis in der frahen griechischen Lyrik. Diss. Munich.

Edmonds, J.M. 1968. Greek Elegy and Iambus, vol. I. Cambridge, Mass.: Harvard University Press. (Loeb Classical Library.)

Gentili, B. 1965. Comment in: Della Corte, F. et al. "Mimnermo." Maia 17:366-387.

Gentili, B. \& Prato, C. 1979. Poetae elegaici testimonia et fragmenta. Pars I. Leipzig: B.G. Teubner Verlaggesellschaft.

Gerber, D.E. 1975. "Mimnermus, Fragment 2.4-5." GRBS 16:263-268.

Gerber, D.E. 1976. "Studies in Greek Lyric Poetry: 1967-1975." CW 70:65-157.

Goldhill, S. 1991. The Poet's Voice. Essays on Poetics and Greek Literature. Cambridge: University Press.

Griffith, M. 1976. "Man and the Leaves: A Study of Mimnermus fr. 2." CSCA 8:73-88.

Latacz, J. 1991. Die griechische Literatur in Text und Darstellung, Band I: Archaische Periode. Stuttgart: Reclam.

Lesky, A. 1966. A History of Greek Literature (transl. C. de Heer \& J. Willis). London: Methuen.

Schadewaldt, W. 1933. "Lebenszeit und Greisenalter im frühen Griechentum." Die Antike 9:282-302.

Schmiel, R. 1974. "Youth and Age: Mimnermus 1 and 2." RFIC 102:283-289.

West, M.L. 1972. Iambi et elegi Graeci ante Alexandrum cantati. Oxford: Clarendon Press. 


\section{A P P E N D I X}

\section{Text 1 (fr. 1 West)}

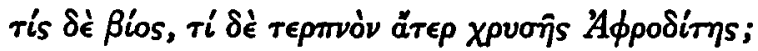

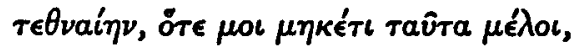

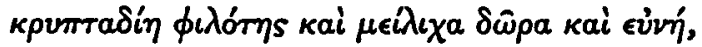

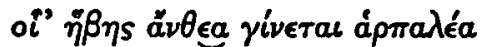

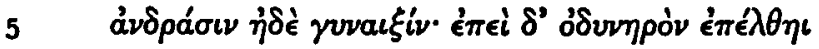

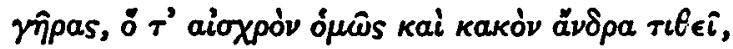

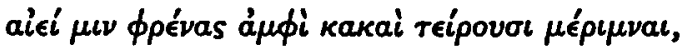

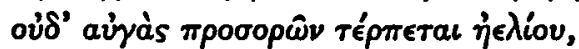

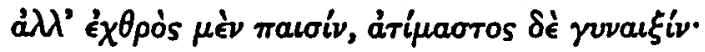

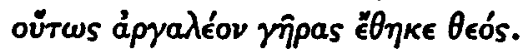

"What life is there, what pleasure without golden Aphrodite?

May I die when I no longer enjoy such things as secret love and persuasive gifts and the bed, which are the flowers of youth, attractive to men and women. And when painful old-age comes, that makes a man both ugly and no-good, evil cares always rub away around his heart, nor does he enjoy seeing the sun's rays. Instead, he's hated by all, despised by women. So painful has God decreed old-age." 


\section{Text 2 (fr. 2 West)}

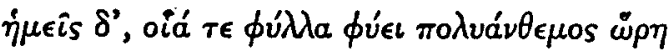

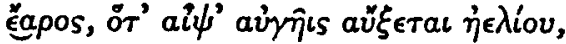

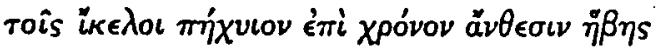

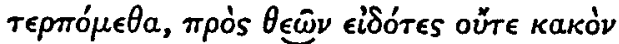

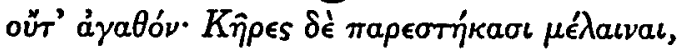

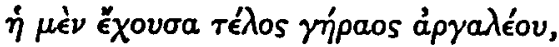

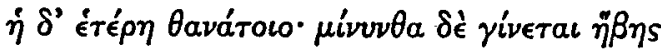

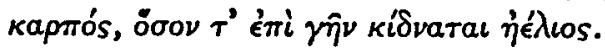

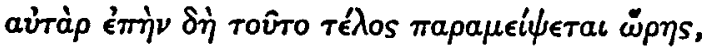

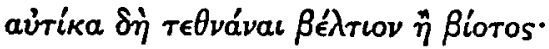

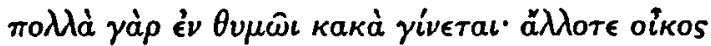

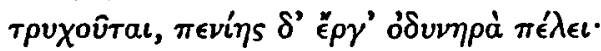

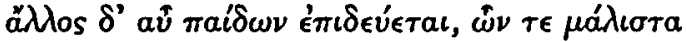

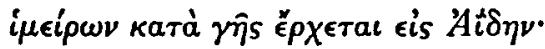

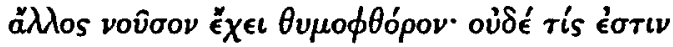

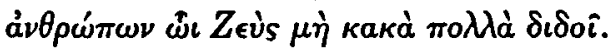

"But we, like leaves that flowering springtime brings forth, when they suddenly grow with the sunlight, like them we enjoy for a short time the flowers of youth, without foreknowledge of evil or good from the gods. The Fates stand right here, black, the one with the lot of a painful old-age, the other of death; and the harvest of youth is as brief as when the sun shines on the land.

But when indeed this period of life has passed away, then straightaway death is better than life.

For many ills arise in the heart; sometimes one's house crumbles, and the painful deeds of poverty come.

Or a man has no children, and for them especially he yearns as he goes below the earth to Hades.

Soul-destroying disease grips another. There's no-one among men to whom Zeus does not give many woes." 


\section{Text 3 (fr. 5 West)}

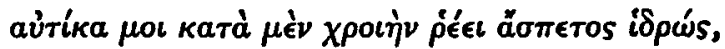

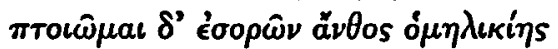

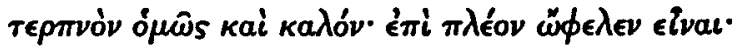

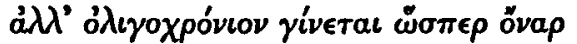

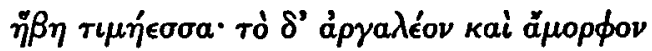

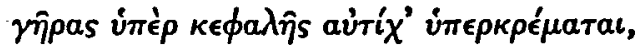

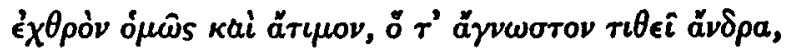

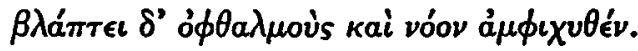

"Suddenly an indescribable sweat runs down my flesh and I tremble when I see my generation's pleasing and lovely bloom, for I wish it were longer. But short-lived as a dream is precious youth; but painful and misshapen old-age hangs directly over our heads, hateful and unhonoured, that makes a man unknown, and harms his eyes and shrouds his mind."

\section{Text 4 (fr. 6 West)}

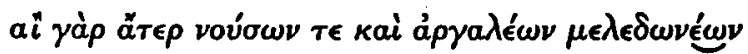

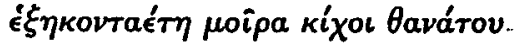

"May, without disease and painful cares, the fate of death overtake me when I'm sixty." 